\title{
PENGEMBANGAN LKPD BERORIENTASI INKUIRI TERBIMBING UNTUK MENINGKATKAN LITERASI SAINS PADA MATERI FAKTOR- FAKTOR YANG MEMPENGARUHI LAJU REAKSI
}

\section{DEVELOPMENT OF STUDENT WORKSHEET WITH GUIDED INQUIRY ORIENTED TO IMPROVE SCIENTIFIC LITERACY ON FACTORS THAT INFLUENCE THE REACTION RATE MATTER}

\author{
Qurrotul Ain dan *Mitarlis \\ Jurusan Kimia FMIPA Universitas Negeri Surabaya \\ e-mail: $\underline{\text { mitarlis@unesa.ac.id }}$
}

\begin{abstract}
Abstrak
Penelitian ini bertujuan untuk mendeskripsikan kelayakan LKPD berorientasi inkuiri terbimbing untuk meningkatkan kemampuan literasi sains pada materi faktor-faktor yang mempengaruhi laju reaksi. Metode penelitian pengembangan menggunakan model pengembangan perangkat yang disarankan oleh Thiagarajan yaitu model 4-D yang dibatasi hanya sampai tahap develop. Ukuran kelayakan ditinjau berdasarkan 3 aspek, yaitu: validitas, kepraktisan, dan keefektifan. Validitas ditinjau berdasarkan kriteria isi, penyajian, kebahasaan, dan kegrafikan. Kepraktisan diperoleh melalui respon dan aktivitas peserta didik selama pembelajaran menggunakan LKPD yang dikembangkan. Sedangkan keefektifan ditinjau melalui tes kemampuan literasi sains yang diujikan secara terbatas kepada peserta didik SMAN 1 Kebomas Gresik sebanyak 12 orang dengan pembelajaran menggunakan model inkuiri terbimbing. Analisis data menggunakan metode deskriptif kuantitatif. Hasil menunjukkan persentase validitas LKPD masing-masing kriteria mendapat skor diantara $80 \%-89,63 \%$ dan dinyatakan valid. LKPD yang dikembangkan mendapatkan respon yang positif dengan persentase sebesar 97,5\% dan dinyatakan sangat praktis serta didukung aktivitas peserta didik yang sangat baik dengan persentase sebesar 98,62\%. Hasil peningkatan kemampuan literasi sains tergambar dalam skor $\mathrm{N}$-Gain yang diperoleh pada rentang $0,45-$ 1,00 dengan kategori sedang-tinggi, untuk $N$-Gain 3 domain yang terikat satu sama lain (konteks, pengetahuan, dan kompetensi) mendapat skor 0,77 dengan kategori tinggi, sedangkan domain sikap mendapat skor $\mathrm{N}$-Gain sebesar 0,33 dengan kategori sedang, didukung dengan ketuntasan klasikal pada tes akhir memperoleh persentase sebesar 100\%, sehingga LKPD dinyatakan efekif.
\end{abstract}

Kata kunci: Lembar Kerja Peserta Didik, Inkuiri Terbimbing, Literasi Sains.

\begin{abstract}
This study intends to describe the feasibility of student worksheet with guided inquiry-oriented to improve the ability of scientific literacy on factors that influence the reaction rate matter. The development research method uses the device development model suggested by Thiagarajan which is a 4$D$ model that is limited to the develop stage. Feasibility measure were reviewed based on 3 aspect, namely: validity, praticality, and effectiveness. Validity is reviewed based on content, presentation, linguistic, and graphic criteria. Praticallity is obtained trough the respones and activitiesof student during learning using the developed student worksheet. While effectiveness is reviewed trough test of scientific literacy skills that were tetsted limited to 12 students of Senior High School 1 Kebomas Gresik by using the guided inquiry model. Analysis of the data uses quantitative descriptive methods. The results show the percentage of student worksheet validity of each criterion scores between $80 \%-89.63 \%$ and declared valid. The developed student worksheet received a positive response with a percentage of $97.5 \%$ and was declared very practical and supported by very good student activity with a percentage of $98.62 \%$. The results of increasing scientific literacy ability are illustrated in the N-Gain score obtained in the range of 0.45-1.00 in the medium-high category, for $N$-gain 3 domains that are bound to each other (context, knowledge, and competence) get a score of .,77 with a high category, while the attitude domain received an $\mathrm{N}$-gain score of 0.33 in the medium category, supported by classical completeness in the final test, getting a percentage of $100 \%$, so that the student worksheet was declared effective.
\end{abstract}

Key words: Student Worksheet, Guided Inquiry, Scientific Literacy.

\section{PENDAHULUAN}

Pendidikan semakin memiliki peranan penting pada masyarakat dan merupakan suatu kunci dalam membentuk dan membangun cara hidup setiap manusia. Tujuan pendidikan diadaptasikan dan dikembangkan sesuai jaman 
yang terus maju, termasuk juga keharusan dalam penyesuaian kurikulum, serta diperlukannya pelatihan dan pengakomodasian berbagai jenis keterampilan dalam komunikasi global [1]. Kemajuan IPTEK di berbagai negara meningkat pesat pada abad 21 [2].

Pemerintah Indonesia telah mengambil tindakan dalam bidang pendidikan yaitu diluncurkannya kurikulum 2013 [3]. Kurikulum 2013 merekomendasikan suatu perencanaan yang bersifat saintifik agar tujuan kurikulum dapat tercapai, yaitu dengan melakukan pembelajaran yang interaktif, inspiratif, memotivasi, menantang, dan sekaligus menyenangkan agar peserta didik menjadi pebelajar yang aktif guna mencari informasi, serta memberikan wadah yang cukup untuk mengembangkan kreativitas dan kemandirian yang disesuaikan dengan perkembangan mental dan fisik juga bakat serta minat peserta didik [4]. Tujuan tersebut dapat diwujudkan melalui proses pendidikan yang diperlukan untuk membuat peserta didik sadar akan pentingnya sains dan teknologi yang dibutuhkan dalam kehidupan.

Sains dan teknologi serta pendidikan di tingkat internasional pada kehidupan abad 21 berkembang dengan pesat, sehingga pembelajaran sains diharapkan mampu memenuhi tuntutan kemampuan di abad-21 [5]. Pembelajaran sains memiliki tujuan umum yaitu menjadikan peserta didik memiliki dan menguasai kemampuan literasi sains serta membantu memahami sains termasuk isi-proses-lingkup dalam kehidupan sehari-hari yang lebih luas [6].

Literasi sains menurut PISA (2015) adalah kemampuan yang dimiliki sebagai warga yang reflektif untuk terlibat isu-isu dan ide-ide terkait ilmu pengetahuan [7]. Studi Internasional PISA terkait literasi sains pada tahun 2012, dan tahun 2015 meningkat. Akan tetapi, masih dibawah ratarata negara OECD. Apabila laju peningkatan terus ditingkatkan, maka capaian Indonesia pada tahun 2030 akan sama dengan capaian negara-negara OECD [5]. Sedangkan, studi PISA tahun 2018 yang baru saja dirilis, peringkat Indonesia menurun pada kemampuan literasi sains yaitu mendapatkan rata-rata skor 396, dan menjadikan Indonesia menempati peringkat 9 dari bawah (71) [8].
Literasi sains di Indonesia rendah diakibatkan salah satu sebab yaitu penggunaan metode pembelajaran yang kurang tepat sehingga tidak memfasilitasi berkembangnya literasi sains peserta didik [9]. Kemampuan literasi sains erat hubungannya dengan pembelajaran bermakna [10]. Pembelajaran akan menjadi bermakna jika peserta didik secara lansung terlibat di dalamnya dengan menerapkan tipe pembelajaran yang berpusat pada peserta didik, diantaranya peer discussion, problem based learning, peer teaching, dan inquiry-based learning [11].

Salah satu model pembelajaran yang tepat untuk peserta didik aktif mencari adalah model inkuiri terbimbing. Pembelajaran ini dapat memposisikan peserta didik sebagai seorang ilmuwan yang akan menemukan atau memecahkan suatu permasalahan melalui kegiatan ilmiah. Oleh karena itu, pembelajaran ini memberikan dampak yang lebih baik dalam melatihkan literasi sains dari pada pembelajaran konvensional [12]. Hal ini juga diperkuat oleh penelitian Imansari, Sudarmin, \& Sumarni (2018) bahwa penerapan model pembelajaran inkuiri dapat melatih kemampuan literasi kimia peserta didik [13]. Sedangkan hasil pra penelitian pembelajaran yang telah dilakukan selama ini paling banyak menggunakan metode ceramah dan diskusi, sedangkan eksperimen hanya mendapatkan persentase $15 \%$. Sehingga tahapan model inkuiri terbimbing menurut National Research Council dapat digunakan untuk melatihkan literasi sains [14].

Pelaksanaan model pembelajaran harus menyesuaikan penggunaan bahan ajar yang sesuai. Salah satu bahan ajar adalah lembar kerja peserta didik yang biasanya disebut dengan LKPD dan dimaksud sebagai lembaran-lembaran yang dalamnya berisikan petunjuk, tugas, dan tahapan yang digunakan untuk membantu peserta didik menyelesaikan pekerjaan baik dilakukan secara perorangan maupun tim dalam pembelajaran [15]. Pengembangan LKPD menggunakan model 4-D menurut penelitian yang dilakukan Ainurrohman \& Mitarlis (2019) menunjukkan hasil LKPD yang dihasilkan layak digunakan [16].

Materi yang digunakan dalam LKPD adalah faktor-faktor yang mempengaruhi laju reaksi karena memiliki karakteristik konsep yang 
yang sering dijumpai dalam bentuk fenomena dikehidupan sehari-hari.

Berdasarkan hasil pra penelitian yang dilakukan di SMAN 1 Kebomas Gresik mendapatkan hasil bahwa media yang digunakan selama ini belum sepenuhnya memudahkan dalam pembelajaran, untuk media berupa LKPD sendiri $70 \%$ menjawab tidak pernah menggunakan LKPD dalam proses pembelajaran. Sebanyak $67 \%$ peserta didik tidak pernah mendengar atau mengenal tentang literai sains. Hasil wawancara dengan salah satu guru memberikan informasi tidak adanya LKPD yang digunakan dalam pembelajaran yang sesuai, dan belum diajarkannya literasi sains kepada peserta didik.

Berdasarkan latar belakang yang telah diuraikan tujuan dari penelitian pengembangan yaitu mendeskripsikan kelayakan LKPD yang dikembangkan, mencakup validitas, kepraktisan, dan keefektifan.

\section{METODE}

Metode penelitian yang digunakan untuk mengembangkan LKPD adalah model 4-D yang dirancang oleh Thiagarajan dan Semmel (1967) untuk pengembangan perangkat. Ada 4 tahapan poses penelitian yaitu define, design, develop, dan disseminate (pendefinisian, perancangan, pengembangan, dan penyebaran) akan tetapi penelitian ini dilakukan sampai tahap ketiga yaitu develop dengan proses uji coba terbatas [17]. Kelayakan LKPD yang dikembangkan berpedoman pada validitas, kepraktisan, dan keefektifan [18].

Sumber data penelitian berasal dari hasil telaah, validasi, dan data hasil uji coba terbatas. Uji coba terbatas terlaksana di kelas X IPA SMAN 1 Kebomas Gresik dengan peserta didik sebanyak 12 orang dengan kemampuan heterogen dan dibentuk kelompok kecil yang menurut Vygotsky peserta didik dapat saling berinteraksi dan mendapat bantuan dari teman sebaya yang ahli [19]. Instrumen yang digunakan yaitu lembar telaah, validasi, angket respon dan observasi aktivitas peserta didik, serta soal pretest dan posttest.

Data telaah dianalisis secara deskriptif kualitatif yaitu hasil masukan dan penilaian oleh ahli/pakar dibidang kimia untuk perbaikan LKPD.
Hasil validasi LKPD selanjutnya dianalisis secara deskriptif kuantitatif, yaitu penilaian berupa angka dan diubah kedalam bentuk persentase. Persentase hasil validasi diperoleh berdasarkan skor kriteria penilaian menggunakan skala Likert yang disajikan pada Tabel 1 .

Tabel 1. Skala Likert

\begin{tabular}{cc}
\hline Nilai Skala & Kriteria \\
\hline 5 & Sangat baik \\
4 & Baik \\
3 & Sedang \\
2 & Buruk \\
1 & Sangat buruk \\
\hline
\end{tabular}

Persentase validitas didapatkan melalui perhitungan dengan rumus (1):

$$
\mathrm{P}(\%)=\frac{\text { Jumlah } \text { skor yang didapatkan }}{\text { skor } \text { kriteria }} \times 100 \%
$$

Keterangan:

Skor kriteria $=$ skor maksimal $\mathrm{x}$ jumlah aspek yang dinilai $x$ jumlah responden

Kemudian, hasil validasi diinterpretasikan menggunakan kriteria pada Tabel 2.

Tabel 2. Kriteria Interpretasi

\begin{tabular}{cc}
\hline Persentase (\%) & Kriteria \\
\hline $0-20$ & Sangat tidak valid \\
$21-40$ & Tidak valid \\
$41-60$ & Cukup valid \\
$61-80$ & Valid \\
$81-100$ & Sangat valid \\
\hline
\end{tabular}

Sesuai kriteria pada Tabel 2, LKPD yang dikembangkan dapat memenuhi kriteria validitas jika memperoleh skor persentase $\geq 61 \%$ dan dinyatakan valid kemudian dapat diuji cobakan secara terbatas dalam pembelajaran.

Angket direspon oleh peserta didik setelah kegiatan uji coba terbatas dan digunakan untuk menunjukkan kepraktisan LKPD yang dikembangkan. Persentase respon diperoleh melalui penggunaan rumus (2):

$$
\mathrm{P}(\%)=\frac{\text { skor } \text { yang didapatkan }}{\text { jumlah peserta didik }} \times 100 \%
$$

LKPD yang dikembangkan dinyatakan praktis jika diperoleh persentase $\geq 61 \%$ dan dinyatakan praktis. 
Kepraktisan juga didukung oleh lembar observasi aktivitas peserta didik yang menggambarkan kegiatan selama penggunaan LKPD yang dikembangkan dalam pembelajaran. Ada dua kriteria keterlaksanaan yaitu ya dan tidak. Aktivitas peserta didik dinyatakan menunjang kelayakan LKPD yang dikembangkan apabila memperoleh persentase $\geq 61 \%$.

\section{Tes Kemampuan Literasi Sains}

Tes diberikan untuk mengetahui deskripsi sejauh mana peningkatan literasi sains yang dialami peserta didik dan hasil ketuntasan belajar sebagai penunjang keefektifan LKPD. Ada 12 soal yang memuat 3 domain literasi sains (konteks, pengetahuan, dan kompetensi). Serta 1 soal yang memuat domain sikap. Tes kemampuan literasi sains dapat dianalisis melalui ketuntasan klasikal, dengan menghitung terlebih dahulu ketuntasan individu dengan nilai di atas KKM (KKM 75), ketuntasan klasikal dapat dihitung menggunakan rumus (3):

Persentase klasikal $(\%)=\frac{\sum T}{\sum S} \mathrm{x} 100 \%$

Dimana: $\sum T=$ jumlah yang tuntas

$\sum S=$ jumlah semua peserta didik

Depdikbud (2014) menyatakan bahwa ketuntasan klasikal memperoleh nilai minimal 85\% [21].

Nilai yang didapatkan dianalisis melalui perhitungan $N$-Gain score. Perhitungan menggunakan rumus (4):

$$
\langle\mathrm{g}\rangle=\frac{\text { skor } \text { posstest }- \text { skor } \text { pretest }}{\text { skor maksimal-skor pretest }}
$$

$\mathrm{N}$-Gain score dikategorikan dalam tiga kategori, jika mendapat skor $<0,3$ berada pada kategori rendah, bila $\geq 0,3$ serta $\leq 0,7$ berada di peningkatan sedang, kemudian skor $>0,7$ meraih peningkatan tinggi [22].

Peserta didik mengalami peningkatan kemampuan literasi sains dan LKPD dinyatakan efektif apabila mendapat skor $N$-Gain $\geq 0,3$.

\section{HASIL DAN PEMBAHASAN}

Penelitian pengembangan ini memperoleh hasil sebagai berikut: hasil tahap pengembangan
LKPD, validitas LKDP, aktivitas dan respon, juga hasil tes kemampuan literasi sains peserta didik.

\section{Tahap Define (Pendefinisian)}

Analisis kebutuhan, kompetensi, peserta didik, tugas, serta konsep dilakukan pada tahap pendefinisian [17]. Hasil dari analisis tersebut adalah rumusan tujuan pembelajaran. Tujuan utama pembelajaran yang dirumuskan yaitu: Peserta didik dapat menjelaskan fenomena, mengevaluasi dan merancang percobaan, dan menafsirkan data dan bukti secara ilmiah.

\section{Tahap Design (Perancangan)}

Pada tahap design dihasilkannya prototipe atau rancangan awal LKPD [17]. Ada 4 LKPD yang dirancang dengan masing-masing memuat 1 faktor yang mempengaruhi laju reaksi. Tahapan dalam LKPD menyesuaikan tahapan inkuiri terbimbing menurut National Research Council (2000) dengan tiap tahapan melatihkan domain literasi sains yang berbeda.

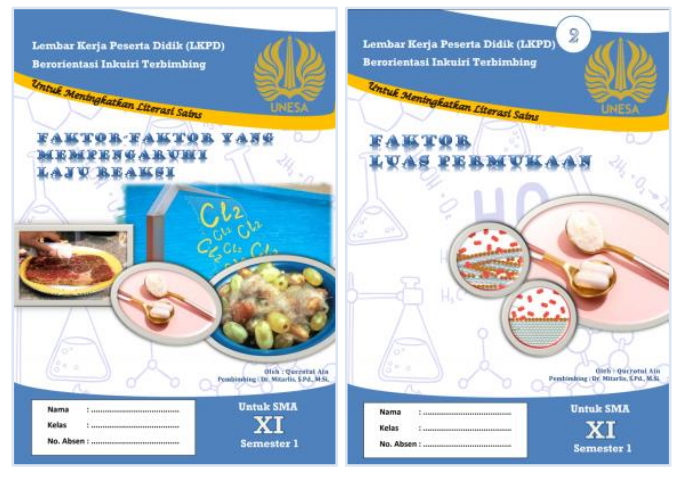

Gambar 1. Contoh Tampilan Cover LKPD; Cover Utama (Kiri) dan Contoh Cover LKPD Sub Judul 2 (Kanan)

Cover utama berisikan 4 gambar yang masing-masing mempresentasikan 4 faktor laju reaksi, yaitu: 1) konsentrasi digambarkan melalui penggunaan kaporit dikolam renang yang membuat kolam renang jernih; 2) luas permukaan diwakili oleh gambar obat utuh dan serbuk; 3) suhu digambarkan pembusukan buah pada suhu ruangan yang lebih cepat; dan 4) katalis yang digambarkan oleh penggunaan katalis seperti enzim pada nanas untuk pengempukan daging sapi. Sedangkan pada cover sub judul fokus pada salah satu faktor dan menambahkan gambar pengaruh tumbukan oleh partikel-partikel. 


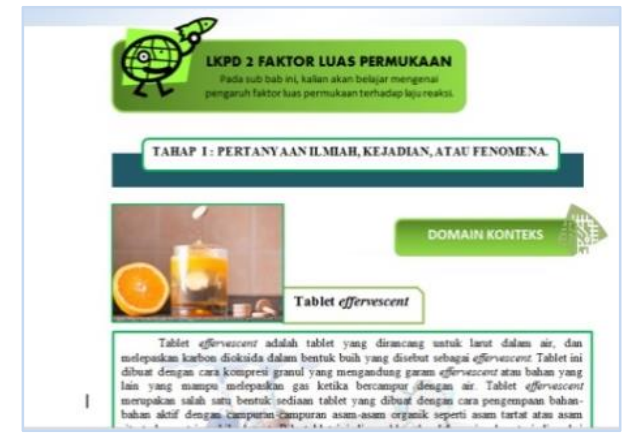

Gambar 2. Contoh Tahapan Inkuiri Terbimbing dalam LKPD

Gambar 1 dan 2 merupakan cuplikan prototipe yang dibuat pada tahap perancangan sesuia hasil analisis yang telah dilakukan sebelumnya.

\section{Tahap Develop (Pengembangan)}

Hasil dari tahap develop adalah seperangkat bahan ajar yang sudah melalui perbaikan yang didasarkan pada saran penelaah maupun validator [17]. Proses yang dilaksanakan yaitu validasi perangkat diikuti revisi kemudian dilakukannya uji coba terbatas menggunakan LKPD hasil revisi. Validator yaitu dosen kimia Unesa sebanyak 2 orang dan guru kimia SMAN 1 Kebomas Gresik. Uji coba terbatas dilakukan pada tanggal 11 Maret 2020 dengan total penggunaan 6 jam pelajaran untuk 4 LKPD.

Berikut produk LKPD yang digunakan uji coba terbatas dalam kegiatan belajar menggunakan model inkuiri terbimbing.

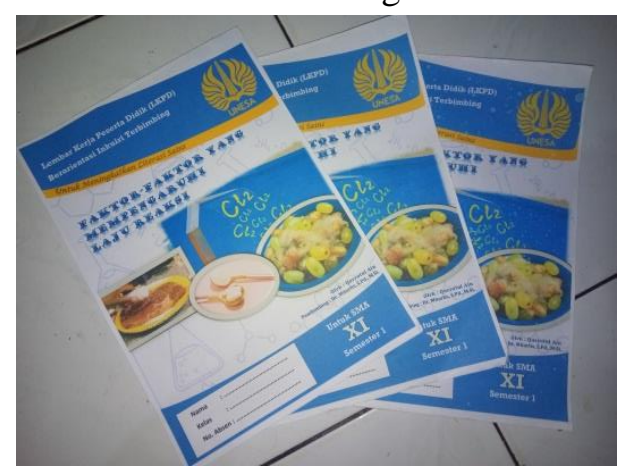

Gambar 3. Produk LKPD Berorientasi Inkuiri Terbimbing untuk Meningkatkan Literasi Sains

\section{Validitas}

Validitas LKPD yang dikembangkan ditinjau dari validitas isi, penyajian, kebahaasaan, dan kegrafikan. Kegiatan validasi diperlukan untuk perbaikan LKPD yang dikembangkan berdasarkan saran yang telah dikemukakan oleh ahli, kemudian LKPD yang telah diperbaiki digunakan untuk uji coba terbatas [17]. Validitas isi dilihat berdasarkan relevansinya dengan tujuan pembelajaran. Berikut disajikan data hasil validasi.

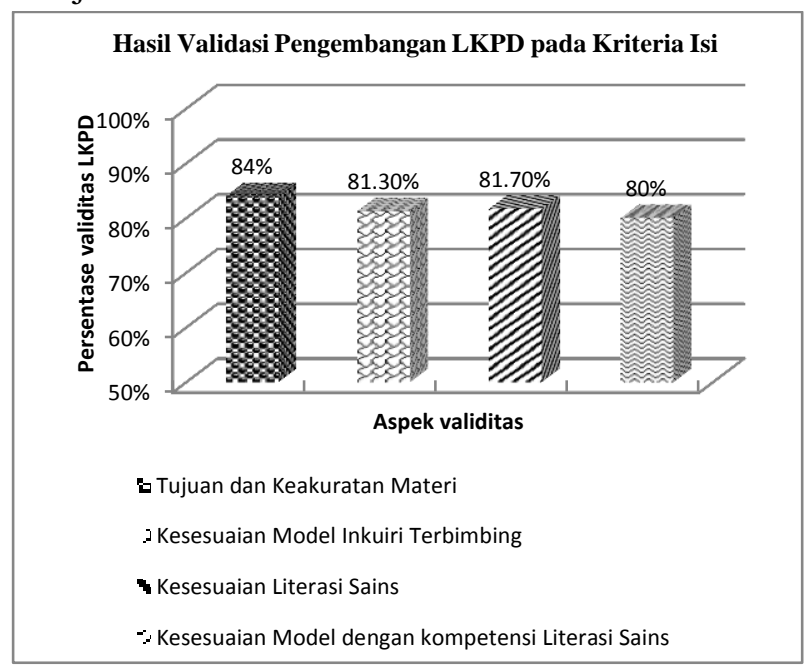

Gambar 4. Hasil Validasi Pengembangan LKPD pada Kriteria Isi

Data hasil validasi pada kriteria isi yang terdiri dari 4 aspek validitas, pertama menunjukan aspek tujuan dan keakuratan materi yang terdiri dari kesesuaian indikator dengan kompetensi dasar, keakuratan fakta, kesesuaian pertanyaan dengan materi, kesesuaian kegiatan penemuan konsep dengan materi dan tujuan pembelajaran, serta kesesuaian kegiatan pemecahan masalah dengan materi mendapatkan persentase sebesar 84\% dengan kategori sangat valid. Aspek kedua yaitu kesesuaian dengan model pembelajaran inkuiri terbimbing yang mencakup 5 tahap pembelajaran mendapatkan persentase $81,30 \%$ menyatakan kategori sangat valid. Aspek ketiga merupakan kesesuaian dengan domain literasi sains yang mencakup domain konteks, pengetahuan, kompetensi, dan sikap memperoleh persentase sebesar $81,70 \%$ dengan kategori sangat valid. Keempat, merupakan aspek kesesuaian model inkuiri terbimbing dengan kompetensi literasi sains medapatkan persentase $80 \%$ dengan kategori valid. Kriteria isi sangat menentukan pencapaian tujuan pembelajaran yang diinginkan dengan menyesuaikan penggunaan model pembelajaran.

Validitas penyajian, kebahasaan, dan kegrafikan bertujuan untuk menghasilkan desain yang logis dan konsisten, hal ini menunjang kualitas LKPD yang dihasilkan [18]. 


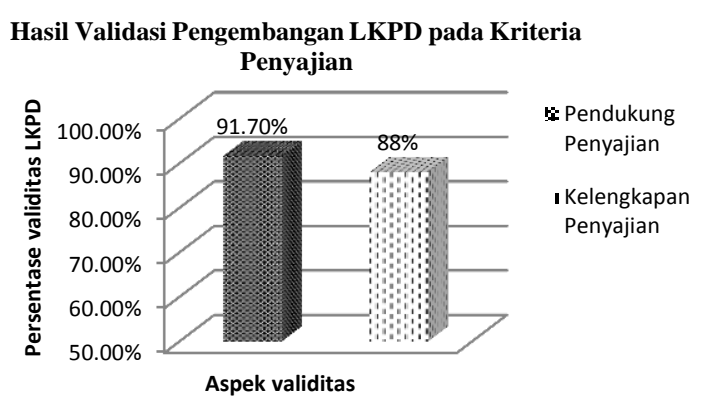

Gambar 5. Hasil Validasi Pengembangan LKPD pada Kriteria Penyajian

Kedua aspek menunjukkan persentase yang tinggi dengan kategori masing-masing sangat valid. Aspek pada kriteria penyajian terdiri dari pendukung penyajian dan kelengkapan penyajian.

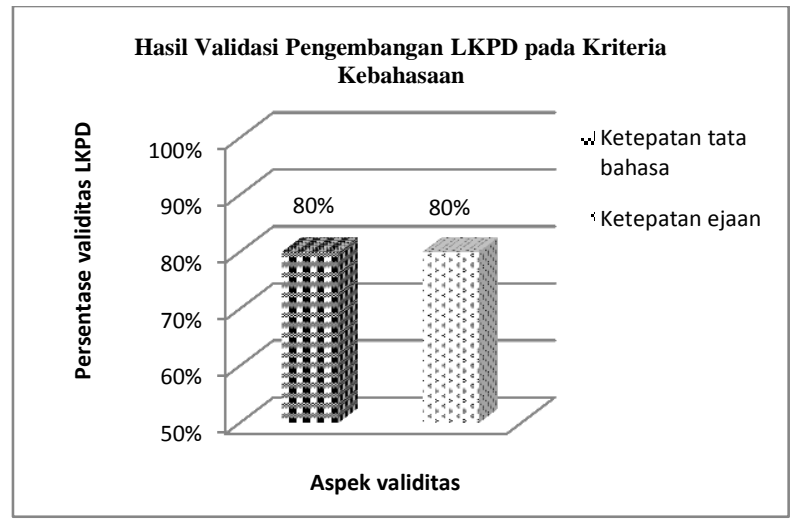

Gambar 6. Hasil Validasi Pengembangan LKPD pada Kriteria Kebahasaan

Dapat diketahui bahwasanya kedua aspek pada kriteria bahasa mendapatkan persentase yang sama yaitu sebesr $80 \%$ dengan kategori valid.

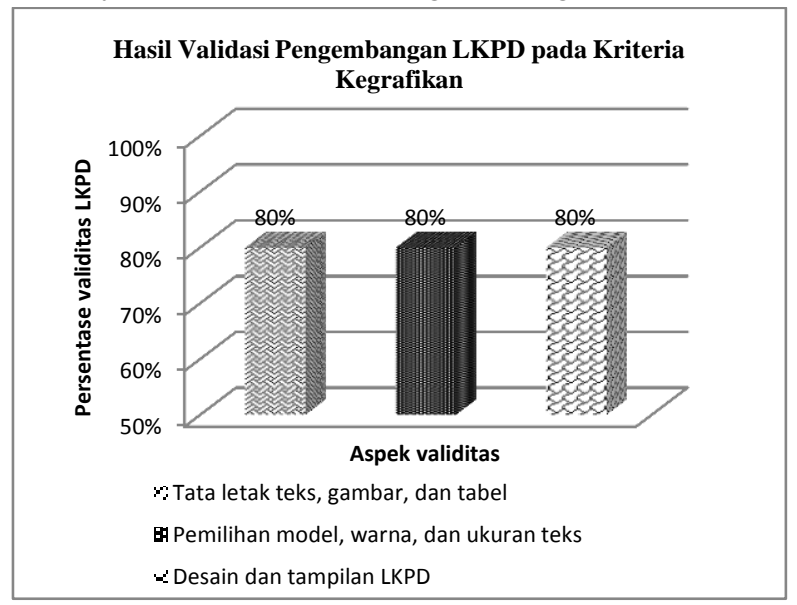

Gambar 7. Hasil Validasi Pengembangan LKPD pada Kriteria Kegrafikan

Ketiga aspek pada kriteria kegrafikan yaitu tata letak, model, dan desain dalam kategori valid, menunjukkan bahwa terdapat keseimbangan dalam
3 aspek dalam menyampaikan pesan yang terdapat dalam LKPD.

Berdasarkan validitas isi, penyajian, kebahasaan dan kegrafikan LKPD yang dikembangkan layak digunakan, hal ini relevan dengan hasil penelitian Latifah dan Dwiningsih bahwa LKS berorientasi literasi sains valid dari segi isi, penyajian, kebahasaan, dan kegrafikan [23].

\section{Kepraktisan}

Kepraktisan bertujuan untuk mengetahui bahwa LKPD dapat secara nyata digunakan dalam pembelajaran dengan tahapan inkuiri terbimbing. Hal ini ditinjau dari aktivitas pada saat menggunakan LKPD dalam proses belajar dan respon yang diberikan peserta didik tehadap LKPD yang dikembangkan.

\section{Aktivitas peserta didik}

Gambaran kegiatan selama pembelajaran dengan 4 LKPD yang dikembangkan dapat dilihat melalui analisis ini. Aktivitas yang dinilai oleh pengamat mengacu pada keterlaksanaan tahapan inkuiri terbimbing yang telah termuat di dalam LKPD. Penerapan pembelajaran inkuiri ini memposisikan peserta didik sebagai seorang ilmuwan dalam beraktivitas yang mencoba untuk memahami fenomena dan memecahkannya melalui kegiatan ilmiah, serta memberikan penjelasan dari apa yang telah mereka pelajari [11]. Hasil observasi aktivitasnya disajikan pada Gambar 8 .

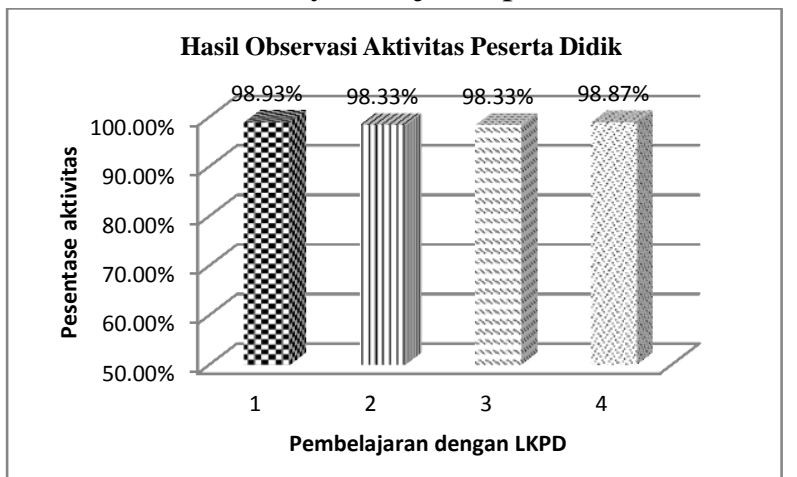

Gambar 8. Hasil Pengamatan Kegiatan Belajar Mengajar dengan LKPD

Melihat gambar 8, keterlaksanaan kegiatan belajar sangat baik menggunakan LKPD yang dikembangkan, tujuan belajar untuk menemukan konsep faktor-faktor yang mempengaruhi laju reaksi telah terlaksana didukung tahapan inkuiri 
terbimbing yang ada dalam LKPD untuk meningkatkan kemampuan literasi sains dibuktikan dengan persentase aktivitas peserta didik yang tinggi pada kegiatan belajar menggunakan LKPD 1, 2, 3, dan 4. Diperkuat dengan penelitian Ristanto, dkk. (2017) bahwa dibandingkan dengan pembelajaran konvensional, penggunan pembelajaran inkuiri terbimbing memberikan dampak yang lebih baik dalam melatihkan literasi sains [12].

\section{Respon Peserta Didik}

Penilaian LKPD oleh peserta didik dilakukan melalui angket yang disebarkan setelah kegiatan uji coba, hasilnya bisa dilihat berikut:

Tabel 3. Hasil Angket Respon Peserta Didik

\begin{tabular}{|c|c|c|c|}
\hline No. & $\begin{array}{l}\text { Pertanyaan berkaitan } \\
\text { dengan LKPD }\end{array}$ & $\mathbf{P}(\%)$ & Kriteria \\
\hline 1. & $\begin{array}{l}\text { Apakah pertanyaan- } \\
\text { pertanyaan dan tugas dalam } \\
\text { LKPD ini menuntun Anda } \\
\text { dalam menemukan konsep } \\
\text { dari faktor-faktor yang } \\
\text { mempengaruhi laju reaksi? }\end{array}$ & 100 & $\begin{array}{l}\text { Sangat } \\
\text { praktis }\end{array}$ \\
\hline 2. & $\begin{array}{l}\text { Apakah LKPD ini } \\
\text { membantu Anda untuk } \\
\text { mengidentifikasi suatu } \\
\text { fenomena secara ilmiah? }\end{array}$ & 100 & $\begin{array}{l}\text { Sangat } \\
\text { praktis }\end{array}$ \\
\hline 3. & $\begin{array}{l}\text { Apakah LKPD ini } \\
\text { membantu Anda untuk } \\
\text { merancang dan } \\
\text { mengevaluasi suatu } \\
\text { percobaan ilmiah? }\end{array}$ & 100 & $\begin{array}{l}\text { Sangat } \\
\text { praktis }\end{array}$ \\
\hline 4. & $\begin{array}{l}\text { Apakah LKPD ini } \\
\text { membantu Anda untuk } \\
\text { menafsirkan data dan bukti } \\
\text { secara ilmiah? }\end{array}$ & 100 & $\begin{array}{l}\text { Sangat } \\
\text { praktis }\end{array}$ \\
\hline 5. & $\begin{array}{l}\text { Apakah LKPD ini } \\
\text { membantu Anda untuk } \\
\text { mengetahui penerapan } \\
\text { konsep dari faktor-faktor } \\
\text { yang mempengaruhi laju } \\
\text { reaksi dalam kehidupan } \\
\text { sehari-hari? }\end{array}$ & 100 & $\begin{array}{l}\text { Sangat } \\
\text { praktis }\end{array}$ \\
\hline 6. & $\begin{array}{l}\text { Apakah penyajian LKPD } \\
\text { ini menambah motivasi } \\
\text { Anda untuk belajar kimia? }\end{array}$ & 91,67 & $\begin{array}{l}\text { Sangat } \\
\text { praktis }\end{array}$ \\
\hline 7. & $\begin{array}{l}\text { Apakah penggunaan } \\
\text { bahasa dalam LKPD ini } \\
\text { dapat dengan mudah Anda } \\
\text { pahami? }\end{array}$ & 91,67 & $\begin{array}{l}\text { Sangat } \\
\text { praktis }\end{array}$ \\
\hline 8. & $\begin{array}{l}\text { Melalui LKPD ini, apakah } \\
\text { Anda dapat } \\
\text { mengaplikasikan konsep } \\
\text { yang telah dipahami untuk } \\
\text { memecahkan masalah pada }\end{array}$ & 100 & $\begin{array}{l}\text { Sangat } \\
\text { praktis }\end{array}$ \\
\hline
\end{tabular}

\begin{tabular}{|c|c|c|c|}
\hline No. & $\begin{array}{l}\text { Pertanyaan berkaitan } \\
\text { dengan LKPD }\end{array}$ & $\mathbf{P}(\%)$ & Kriteria \\
\hline & $\begin{array}{l}\text { suatu konteks yang } \\
\text { diberikan? }\end{array}$ & & \\
\hline 9. & $\begin{array}{l}\text { Apakah tahap-tahap dalam } \\
\text { LKPD ini membuat kalian } \\
\text { mampu menemukan } \\
\text { konsep dan } \\
\text { mengaplikasikan konsep } \\
\text { pada masalah di kehidupan } \\
\text { sehari-hari? }\end{array}$ & 91,67 & $\begin{array}{l}\text { Sangat } \\
\text { praktis }\end{array}$ \\
\hline 10. & $\begin{array}{l}\text { Apakah LKPD ini } \\
\text { membantu Anda untuk } \\
\text { menumbuhkan sikap ilmiah } \\
\text { (minat dalam sains dan } \\
\text { teknologi/ kesadaran akan } \\
\text { masalah lingkungan)? }\end{array}$ & 100 & $\begin{array}{l}\text { Sangat } \\
\text { praktis }\end{array}$ \\
\hline \multicolumn{2}{|c|}{ Persentase rata-rata } & 97,5 & $\begin{array}{l}\text { Sangat } \\
\text { praktis }\end{array}$ \\
\hline
\end{tabular}

Dilihat dari Tabel 3, seluruh indikator yang telah direspon oleh peserta didik berada dalam persentase di atas $81 \%$ dan dinyatakan sangat praktis. Beberapa indikator mendapatkan skor maksimal yaitu persentase sebesar $100 \%$ pada pertanyaan poin $1,2,3,4,5,8$, dan 10 yang seluruhnya berkaitan dengan kriteria isi LKPD. Indikator yang lain mendapatkan persentase sebesar $91,67 \%$ yaitu pada pertanyaan nomor 6,7 , dan 9. Pertanyaan nomor 6 menunjukkan respon dalam kriteria penyajian dan kegrafikan, sedangkan pada nomor 7 menunjukkan kriteria kebahasaan, dan nomor 9 masih berkaitan dengan kriteria isi LKPD.

Langkah yang sangat penting dalam proses inkuiri terbimbing adalah proses inkuiri yang mencakup kompetensi literasi sains salah satunya menjelaskan fenomena ilmiah [12]. Dilihat perolehan respon pada pertanyaan poin 2 menjelaskan bahwa dengan bantuan LKPD proses inkuiri telah terlaksana dan menunjang kepraktisan LKPD.

\section{Keefektifan}

Keefektifan LKPD yang dikembangkan dinyatakan melalui sejauh mana peserta didik paham konsep yang diajarkan melalui penggunaan LKPD yang dikembangkan dan pencapaiannya di akhir kegiatan belajar yang dideskripsikan oleh ketuntasan hasil belajar atau ketuntasan klasikal dan peningkatan kemampuan literasi sains peserta didik. 


\section{Ketuntasan Klasikal}

Hasil belajar individu dinyatakan tuntas jika nilai minimal yang didapatkan sebesar 75 . Depdikbud (2014) menyatakan bahwa ketuntasan klasikal memperoleh persentase minimal $85 \%$. Ketuntasan penting dalam mengukur sejauh mana pemahaman konsep yang diajarkan. Ketuntasan hasil belajar dapat dilihat melalui gambar berikut.

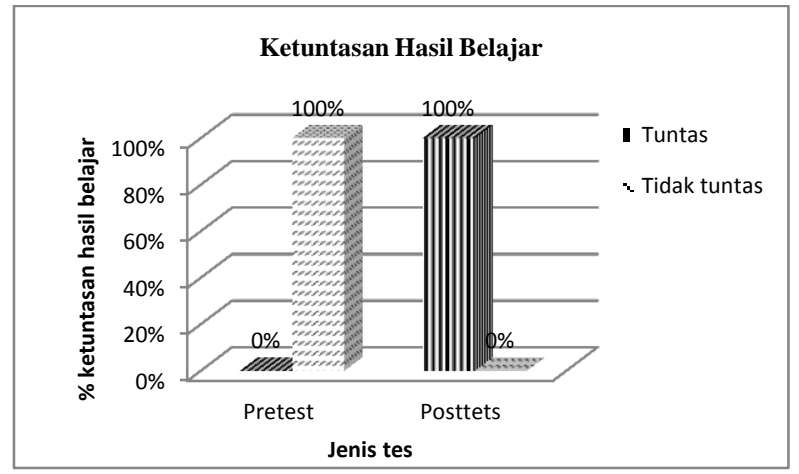

Gambar 9. Ketuntasan Saat Pretest dan Posttest

Berdasarkan gambar 9 dapat diketahui bahwa pada tes awal $0 \%$ peserta didik tuntas. Sedangkan pada tes akhir $100 \%$ peserta didik tuntas. Hal ini menunjukkan ketuntasan klasikal meningkat sebesar $100 \%$. Pada saat pretest seluruhnya tidak tuntas dikarenakan materi faktor-faktor yang mempengaruhi laju reaksi belum diberikan, sedangkan pada saat posttest peserta didik seluruhnya tuntas, hal ini menggambarkan bahwa proses inkuiri telah terjadi saat pembelajaran menggunakan LKPD untuk menemukan konsep mengenai materi yang belum dipelajari. Hal ini sesuai dengan teori belajar konstruktivis menurut Vygotsky bahwasanya peserta didik akan mengkonstruksi pemahamannya sendiri melalui bantuan atau yang disebut scaffolding, LKPD yang diberikan efektif membantu peserta didik memahami konsep yang dipelajari [19].

\section{Peningkatan Kemampuan Literasi Sains}

Domain literasi sains yang diajarkan dan diharapkan meningkat dalam penelitian pengembangan ini ada 4 domain yaitu konteks; pengetahuan; dan kompetensi yang mencakup menjelaskan fenomena ilmiah, merancang dan mengevaluasi penyelidikan ilmiah, menafsirkan data dan bukti ilmiah; serta sikap [7]. Berikut gambaran peningkatan $\mathrm{N}$-gain score.

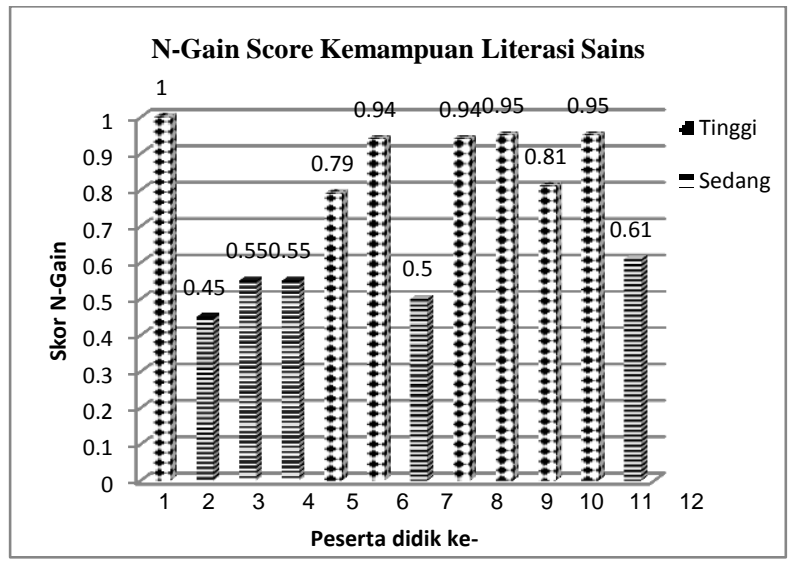

Gambar 10. Skor Hasil Peningkatan Literasi Sains

Berdasarkan hasil N-Gain score kemampuan literasi sains pada gambar 9 dapat dipahami peningkatan kategori tinggi dialami oleh 7 orang karena skor yang didapatkan $>0,7$ dan lainnya sebanyak 5 orang mengalami peningkatan kategori sedang karena mendapatkan skor $>0,3$. Persentase peningkatan kategori tinggi sebesar $58 \%$ dan kategori sedang sebesar $42 \%$. Ada salah satu peserta didik mendapatkan skor $N$-Gain maksimum yaitu peserta didik ke-1. Peningkatan domain literasi sendiri pada 3 domain yang terikat satu sama lain (konteks, pengetahuan, dan kompetensi) mendapat skor 0,77 berkategori tinggi, melainkan pada domain sikap mendapat skor 0,33 berkategori sedang. Hal ini menyatakan LKPD yang dikembangkan sangat efektif guna meningkatkan kemampuan literasi sains. Sesuai dengan penelitian Rahayu bahwa pembelajaran inkuiri dapat meningkatkan literasi dengan mengoptimalkan aspek-aspek literasi yaitu memilih topik kimia yang sesuai kehidupan peserta didik dan mencakup pengetahuan deklaratif, prosedural serta epistemik [3].

\section{SIMPULAN}

Berdasarkan hasil penelitian dan pembahasan, didapatkan kesimpulan bahwa LKPD yang dikembangkan layak digunakan dengan rincian kriteria kelayakan:

1. Validitas LKPD yang dikembangkan mencakup aspek isi, penyajian, kebahasaan, dan kegrafikan memperoleh persentase berturut-urut sebesar $81,85 \%, 89,63 \%, 80 \%$, dan $80 \%$ dengan kategori valid/sangat valid. 
2. Kepraktisan LKPD yang dikembangkan ditinjau dari aktivitas memperoleh persentase sebesar 98,62\% dan respon peserta didik sebesar $97,55 \%$ menunjukkan sangat praktis.

3. Keefektifan LKPD yang dikembangkan dilihat melalui ketuntasan belajar memperoleh persentase sebesar $100 \%$ dengan kategori tuntas dan skor $\mathrm{N}$-gain rata-rata 0,75 dengan kategori tinggi.

\section{SARAN}

Berdasarkan hasil penelitian yang didapatkan, dikemukakan saran sebagai berikut:

1. Memfokuskan salah satu domain literasi sains yang dilatihkan agar pembahasannya lebih mendalam dan terarah.

2. Level literasi sains yang dilatihkan mencakup seluruh level soal dalam literasi sains.

3. Diperhitungkan waktu uji coba terbatas kepada subjek yang sesuai dengan model inkuiri terbimbing yang belum mendapatkan konsep yang akan diajarkan dan telah memiliki materi prasyarat untuk belajar materi faktor-faktor yang mempengaruhi laju reaksi.

\section{DAFTAR PUSTAKA}

1. Suyono, \& Hariyanto. 2015. Implementasi Belajar dan Pembelajaran. Bandung: PT Remaja Rosdakarya.

2. Rusilowati, A., Kurniawati, L., Nugroho, S. E., \& Widiyatmoko, A. 2016. Developing an Instrument of Scientific Literacy Assesment on the Cycle Theme. International Journal of Environtmental and Science Education, Vol. 11 No. 12, 5718-5727.

3. Rahayu, S. 2017. Mengoptimalkan Aspek Literasi dalam Pembelajaran Kimia Abad 21. Prosiding Seminar Nasional Kimia UNY 2017 Sinergi Penelitian dan Pembelajaran untuk Mendukung Pengembangan Literasi Kimia pada Era Global. Yogyakarta: Universitas Negeri Yogyakarta.

4. Permendikbud. 2013. Permendikbud No. 65 Tahun 2013 tentang Standar Proses Pendidikan Dasar dan Menengah. Jakarta: Menteri Pendidikan dan Kebudayaan RI.

5. Kemendikbud. 2017. Materi Pendukung Literasi Sains. Jakarta: Gerakan Literasi Nasional.
6. Toharudin, U., Hendrawati, S., \& Rustaman, A. 2011. Membangun Literasi Sains Peserta Didik. Bandung: Humainora.

7. OECD. 2016. PISA 2015 Result: Excellence and Equity In Education Vol. 1. Kanada: OECD Publishing.

8. Permana, R. H. 2019. Retrieved Desember 8, 2019, from Detiknews.com:

https://news.detik.com/berita/d4808456/survei-kualitas-pendidikan-pisa2018-ri-sepuluh-besar-dari-bawah

9. Fatmawati, I. N., \& Utari, S. 2015. Penerapan Levels of Inquiry untuk Meningkatkan Literasi Sains Siswa SMP Tema Limbah dan Upaya Penanggulangannya. Jurnal Edusains, Vol. 7 No. 2, 152-159.

10. Holbrook, J., \& Raniikkmae, M. 2009. The Meaning of Scientific Literacy. International Journal of Environtmental \& Science Education, Vol. 4 No. 3, 275-288.

11. Rakhmawan, A., Setiabudi, A., \& Mudzakir, A. 2015. Perancangan Pembelajaran Literasi sains Berbasis Inkuiri pada Kegiatan Laboratorium. Jurnal Penelitian dan Pembelajaran IPA (JPPI), Vol. 1 No. 1 , 143152.

12. Ristanto, R. H., Zubaidah, S., Amin, M., \& Rohman, F. 2017. Scientific Literacy of Students Learned Trough Guided Inquiry. International Journal of Research and Review, Vol. 4 No. 5, 23-30.

13. Imansari, M., Sudarmin, \& Sumarni, W. 2018. Analisis Literasi Kimia Peserta Didik Melalui Pembelajaran Inkuiri Terbimbing Bermuatan Etnosains. Jurnal Inovasi Pendidikan Kimia, Vol. 12 No. 2, 2201-2211.

14. National Research Council. 2000. Inquiry and the National Science Education Standards: A Guide for Teaching and Learning/Center for Science, Matematics, and Engineering Education. US America: National Academi of Sciences.

15. Badruzzaman. 2018. Format dan Contoh LKPD Kurikulum 2013. Retrieved January 7, 2020, from dasarguru.com: https://www.dasarguru.com/contoh-lkpdkurikulum-2013/

16. Ainurrohman, A., \& Mitarlis. 2019. Pengembangan Lembar Kerja Peserta Didik dengan Strategi Mind Mapping untuk Meningkatkan Berpikir Kreatif Peserta Didik 
pada Materi Koloid. Unesa Journal of Chemical Education, Vol. 8 No. 1, 67-74.

17. Ibrahim, M., \& Wahyusukartiningsih. 2014. Model Pembelajaran Inovatif melalui Pemaknaan. Surabaya: Unesa University Press.

18. Nieveen, N., Tjeerd, P., Akker, J., Bannan, B., \& Kelly, A. E. 2010. An Introduction to Educational Design Research. Enschede: Netherlands Institute for Curriculum Development.

19. Slavin, R. E. 2011. Psikologi Pendidikan. (M. Samosir, Trans.) Jakarta: PT Indeks.

20. Riduwan. 2012. Skala Pengukuran VariabelVariabel Penelitian. Bandung: Alfabeta.
21. Permendikbud. 2014. Permendikbud No. 104 tahun 2014 tentang Penilaian Hasil Belajar pada Jenjang Dikdasmen. Jakarta: Kementerian Pendidikan dan Kebudayaan.

22. Hake, R. R. 1998. Interactive-engagement vs Traditional Methods. American Journal of Physics, Vol. 66 No. 1, 64-74.

23. Latifah, C., \& Dwiningsih, K. 2018. Pengembangan Lembar Kegiatan Siswa (LKS) Berorientasi Literasi Sains pada Materi Pembelajaran Termokimia Kelas XI SMA. Journal of Chemical Education, Vol. 7 No. 3, 350-357. 